Public health

\section{The poverty of public health in a dominant power}

Nancy Milio

The recent hurricanes in the Gulf of Mexico exposed the poverty of US public health infrastructure, weakened by years of budgetary neglect.

$\mathrm{K}$ atrina and Rita, the unprecedented September hurricanes and massive Gulf of Mexico surge, overpowered the levees of New Orleans and flooded state coastlines. They also exposed the poverty of US public health infrastructure, weakened by years of budgetary neglect.

Tens of thousands of New Orleanians were trapped in the city. They were mostly poor African Americans who had no cars and no access to the limited numbers of buses that were available Fifteen thousand eventually made it to safety in the Astrodome stadium. Thousands more sought refuge in an unattended convention centre, virtually unknown to authorities. Here they attempted to survive in extreme heat, without adequate sanitation, water or food for several days. The ill, elders, and children suffered most; several died; a third had been injured by the storm; $40 \%$ had chronic diseases; a third were without necessary medications. Over half had no health insurance and many were not eligible for Medicaid, the public health insurance for the poor, because they did not fit the narrow categories of that programme-for example, they were not parents of young children. ${ }^{1}$ Worse, dozens of elders were left unattended in nursing homes and medical facilities. As a result, they died; this lead to criminal indictments against culpable health personnel.

The hundreds of thousands of Americans, both citizens and "illegal" residents trapped in coastal towns and cities were vulnerable to this catastrophic disaster because of three failures of public policy: poverty, growing again in recent years, and the dearth of public measures to reduce it; the inadequacy of emergency planning and resources despite years of warning; thirdly, the deterioration of environmental regulation to protect coastal wetlands, land use, and storm mitigation. The question now is whether these health damaging wrongs will be made right.

\section{PEOPLE POVERTY}

In the USA policies that broadly sustain a healthful level of living for people who cannot work or find jobs that pay more than poverty level wages ( $\$ 19000$ for a four person family), have been steadily under funded in recent years and are to be cut further in coming years. These include cash assistance, food stamps, health and child care, housing subsidies, unemployment insurance, and the failure to raise the minimum hourly wage, at \$5.50, unchanged since 1997.

\section{POOR PLANNING}

The linchpins in the national population's health are a handful of separate federal agencies that support each state's health department and 3000 local health departments. Among these are the Centers for Disease Control and Prevention and Environmental Protection Agency (EPA). Each has had cuts of $10 \%-20 \%$ annually, shrinking their efforts in disease prevention, surveillance, community health centres, maternal and child health, and environmental monitoring and regulatory enforcement. Other cuts were made in the Food and Drug Administration and Occupational Health and Safety by as much as $50 \%$.

Although new funds were invested in public health after the September 11, 2001 terrorist attacks, they were narrowly focused, with billions going to drug companies to induce them to produce medications to thwart bioterrorism attacks, such as anthrax. At the same time, public health authority for emergency preparedness was moved from the US Public Health Service to the new huge, 170000 employee, 23 agency Department of Homeland Security (DHS). Public health preparedness thus became more vulnerable to budget and personnel cuts. All DHS workers, under new imposed work rules, can be moved from one agency to another, resulting in diminished expertise. Many tasks were outsourced to commercial firms with non-unionised workforces, making DHS oversight and coordination difficult at best. ${ }^{2}$

Authoritative reports recently examined public health preparedness. They found that future financing plans will be $\$ 100$ billion short of meeting needed improvements. Two thirds of the states' health departments lacked funds and workforce expertise; lacking too was a comprehensive national information network for communication and coordination among local, state, federal efforts.

FEMA, the Federal Emergency Management Agency, was once the lead independent federal agency for dealing with disasters, gaining a reputation for quick and efficient aid to states and communities during the 1990s. It too was enveloped in the DHS and vulnerable to programme cuts and new leadership after September 11. During the Katrina emergency it was widely acknowledged to have failed; the head, a political appointee, resigned within days.

The well known key ingredients for effective planning include clear goals and a strategy based on defined responsibilities of all major stakeholders; mechanisms for decision making, coordination and communications-and resources: money, people, supplies, expertise. It also requires the use of reliable information, preferably science based.

The science data before Katrina were clear. They were summarised and published by an investigative reporter in May 2005 after reviewing years' worth of government and academic reports:

\section{A slow-moving Category 4 [140 miles/hour] or 5 [170 miles/hours] hurricane...could generate a 20 foot surge that would easily over- whelm the levees of $\mathrm{New}$ Orleans....the geographical "bowl" of the City would fill up with the waters of the lake, leaving those unable to evacuate with little option but to cluster on rooftops.... The water itself would become a fester- ing stew of sewage, gasoline, refin- ery chemical, and debris... New Orleans could furnish perhaps the largest natural catastrophe ever experienced on US soil. ${ }^{3}$}

Just before the Bush Administration in 2001, FEMA had been offering disaster mitigation grants to states to help repair the flood protection levees of New Orleans. These were eliminated. FEMA had cited a hurricane strike on the city as one of three worst most probable natural disasters that could occur in the USA. At the same time, the Army Corps of Engineers, whose job is to protect 
flood prone land, asked Congress for \$430million to shore up the levees. Louisiana Congressional officials sought \$14billion to revive the coastal wetlands, but got only \$ 0.57billion. By 2004, the Administration instead had cut funding by $80 \%$, and what was available was often spent on less than necessary water projects in Louisiana to support industry, with limited regard for environmental damage while destroying millions of acres of storm blocking wetlands. ${ }^{4}$

\section{ENVIRONMENTAL IMPOVERISHMENT}

The health risks raised by the disregard of poverty by policymakers and the inadequacy of public health and safety preparedness agencies were multiplied by the decline in environmental protection. Beyond continuous budget cuts in recent years, the EPA became newly headed by political rather than professional appointees. It redefined regulatory terms such that "wetlands" - which were not to be used for economic developmentbecame open to commercial purposes in the Gulf region, weakening the shoreline buffer against storm surges. In line with the Administration's policy to lighten government regulation of business, it focused on re-writing rules protecting drinking water and air; asbestos and mercury elimination, and as most widely known, global climate change.

As a case in point, an environmental official in the White House, a former Petroleum Institute lobbyist, edited an EPA climate change report so as to raise uncertainties about whether global warming is occurring and downplaying potential damage. (He soon resigned and went to work for the giant oil firm Exxon-Mobile.)

Katrina and Rita revealed another facet of climate change that policymakers are not acknowledging. Over 2 million evacuees mandated to leave Houston, Texas during Rita were caught in gridlock on the expressways because there were too many cars. People in New Orleans were caught in town because they had no cars. What they shared with all Americans is a dependence on carsthe mark of "freedom" to move "whenever and wherever". That devotion adds to US oil dependence, which makes a large contribution to imprisoning the world's population under a thickening blanket of water warming greenhouse gases, intensifying hurricanes.

\section{WHAT NEXT?}

The Administration's answer to auto-oil dependence is to promote more of the same. The Governor of Louisiana wants billions to build more highways for the next evacuation. The Department of Interior is planning to expand energy development on public lands, including the pristine Alaska National Wildlife Reserve and the nation's coastal waters, ending a 25 year moratorium. The new Energy Act provides many billions mainly to promote fossil fuel industries.

With a projected \$150-200 billion needed to restore New Orleans and surround-which has one of the highest poverty rates in the country-the majority Republican Party's Study Group proposed to cut the 2005-2006 budget further to pay the disaster's costs, producing $\$ 370$ billion in "savings" over five years. These cuts involve the services and protections that were already deficient and helped create the vulnerabilities of
New Orleans and the coastal poor, including health and education programmes, home care, energy conservation; water quality and wastewater infrastructure; high speed rail development and new public transit; neighbourhood investment and minority business development, legal services for the poor and local emergency worker grants. ${ }^{5}$

In the new century, US leaders' commitment has been to "free market" solutions to public issues. This wake up moment could be more healthfully used to restore financing to reduce poverty to at least European levels; to rebuild adequate public health and safety capacity, and to enable tools to protect environments, moving toward a new energy future, for example, a national intercity rail system, linking small and large cities, spurring rural development, new transportation options, conservation, energy efficiency technologies and buildings, new energy sources and new good jobs, training and education, discouraging sprawl and energy expensive houses.

J Epidemiol Community Health 2006;60:2-3. doi: 10.1136/jech.2005.042663

Correspondence to: Professor $\mathrm{N}$ Milio, Carrington Hall, number 7460, University of North Carolina, Chapel Hill, NC 27599-7460, USA; nancy_milio@unc.edu

\section{REFERENCES}

1 Center on Budget and Policy Priorities. Katrina evacuees ineligible for Medicaid. 26 Sep 2005. http://www.cbpp.org

2 Government Accountability Office. Federal agencies face challenges in implementing initiatives to improve public health infrastructure. Jun 2005. http://www.gao.gov

3 Moody C. Frail disaster preparation. Am Prospect 2005;5:23.

4 Editorial. New York Times 2005:Sep 13.

5 Republican Study Group. Budget Options for 2005-06. 22 Sep 2005. http://www.house.gov

Brazil. In 1999, the child mortality rate in the north eastern region of Brazil was $52.4 / 1000$, while in the southern region it was 17.2/1000 live births. ${ }^{2}$ A population based investigation performed in 1990-1991, in two cities in the north east $^{3}$ found $40 \%$ of avoidable deaths among the absolute total of children who died aged less than 1 year. One of the strategies of the Ministry of Health to develop the National Health System (SUS), bringing together effectiveness and equity, has been to extend the primary health care network through the Family Health Program (PSF, Programa Saúde da Família). The PSF intends to increase access to health care services, contributing to universalise care, in a context of limited resources. The social groups targeted by this strategy were initially those with greater socioeconomic vulnerability, so as to contribute to reducing the inequities in 